\title{
Aplikasi Teori Double Movement Fazlu Rahman terhadap Kasus Poligami
}

Beta Firmansyah

Betafirmansyah6@gmail.com

Abstrak: Permasalahan poligami menjadi perbincangan yang hangat dikalangan para ulama. Para ulama klasik cenderung membolehkan praktik poligami, sedangkan ulama kontemporer melarang praktik perpoligamian. Maka dari itu tulisan ini mencoba meninjau kembali hukum poligami dengan menggunakan teori double movement Fazlu Rahman. Dalam tulisan ini terlihat bahwa kebolehan poligami dikarenakan kondisi sosial ketika islam belum datang, dan penulis mendapatkan nilai moral yang dikandung dalam hukum ini adalah ingin mengangkat harkat martabat kaum perempuan. Maka dari itu, penulis berkesimpulan bahwa pembatasan menjadi empat orang adalah hal yang mengisyaratkan bahwa perpoligamian itu dilarang dalam islam.

Kata Kunci : Poligami, Fazlu Rahman, dan Double Movement

\section{A. Pendahuluan}

Al-Qur'an diturunkan oleh Allah sebagai petunjuk bagi manusia. Setiap ayat dan ketetapan hukum yang ada dalam al-Qur'an memiliki tujuan dan hikmah tersendiri untuk kemaslahatan manusia. Disyari'atkannya hukum tentu memiliki tujuan dan maslahat yang dikehendaki oleh syar'i, karena Allah tidak mensyariatkan hukum kecuali memiliki kemaslahatan bagi hamba-Nya, yaitu untuk tatanan kehidupan umat-Nya baik di dunia maupun di akhirat. ${ }^{1}$

Salah satu hukum yang Allah sebutkan dalam al-Qur'an bagi hamba-Nya adalah hukum poligami. Allah berfirman tentang hukum menikahi wanita lebih dari satu, yaitu dua, tiga sampai empat jika memang bisa berlaku adil. ${ }^{2}$ Ayat ini yang dijadikan dalil bahwa berpologami itu diperbolehkan dalam syari'at islam, terutama para 
ulama klasik memang melegalkan poligami bahkan mereka menyebutkan hikmah yang terkandung dalam hukum berpoligami, misalnya adalah untuk menghindari terjadinya hubunngan seks di luar nikah. $^{3}$

Akan tetapi, dalam konteks sebagian negara - misalkan Indonesia - berpoligami walaupun diperbolehkan itu adalah hal yang tabu. Artinya, ketika seorang melakukan poligami dia dipandang "miring" oleh masyarakat, apalagi itu dilakukan oleh tokoh agama atau masyarakat. Misalkan apa yang terjadi pada dai kondang AA Gym, ketika beliau mencapai popularitasnya, lalu dia menyatakan bahwa dirinya berpoligami, maka popularitasnya seketika jatuh bahkan beliau dijauhi dan dicaci. ${ }^{4}$

Memang kebolehan para ulama klasik untuk berpoligami dilandasi penafsiran mereka yang bersifat literalis. Mereka tidak melihat konteks yang ada ketika hukum itu turun dan konteks kekinian yang sebenarnya berbeda. Sehingga mereka menerapkan hukum sesuai dengan apa yang ada didalam teks. Akan tetapi merekapun gagap dalam menghadapi masalah-masalah yang konteknya berbeda dengan konteks zaman nabi. ${ }^{5}$ Sehingga menjawab tantangan zaman adalah jargon yang kencang diperbincangakan dalam pemikiran islam pada masa kini tidak terkecuali fiqh. Indikatoranya adalah semakin banyaknya upaya pembaharuan pemikiran hukum islam baik dilakukan oleh sarjana muslim maupun oleh sarjana-sarjana orientalis. ${ }^{6}$

Salah satunya adalah Fazlu Rahman, beliau adalah tokoh pembaharu yang datang dari Pakistan. Beliau menawarkan sebuah teori dalam memahami teks al-Qur'an terutama dalam memahami fiqh. Beliau merekontruksi kembali pemahaman fiqh yang selama ini digandrungi oleh ulama klasik. Teortinya adalah double movement, dalam teori ini Fazlu Rahman memberikan dua gerakan, gerakan pertama manggunakan tiga pendekatan, yaitu pendekatan historis, kontekstualis, dan sosiologis. Sedangkan gerakan kedua yaitu perumusan prinsip, nilai dan tujuan al-Qur'an yang telah didapatkan dalam gerakan pertama dan disesuaikan dengan konsteks yang aktual. ${ }^{7}$

Maka dari itu tulisan ini ingin mencoba menijau kembali hukum poligami dengan menggunakan teori double movement yang digagas oleh Fazlu Rahman. Alasan penulis menggunakan teori ini karena teori ini melihat konteks ketika hukum ini diturunkan dengan konteks saat ini sehingga menurut penulis akan melihat hubungan antara tujuan syariat dengan tuntutan zaman. Dalam tulisan ini penulis menggunakan metode deskriptif-analisis. Yaitu mendeskripiskan tentang poligami dan konteks pada saat itu lalu melakukan analisi 
dengan cara mencari nilai moral dari poligami itu lalu menerapkannya konteks kekinian.

\section{B. Diskursus Tentang Poligami}

Ada tiga pendapat tentang poligami, yaitu pertama, pendapat yang membolehkan poligami secara longgar bahkan mereka mengatakan bahwa poligami itu adalah sunnah nabi saw. Pendapat ini mengabaikan syarat keadilan yang disebutkan dalam ayat 3 surah al-Nisa tersebut. Kedua, pendapat yang membolehkan poligami secara ketat, dengan syarat yaitu pemenuhan hak ekonomi dan seksual bagi para istri. Ketiga, pendapat yang melarang secara mutlak. ${ }^{8}$

Perdebatan masalah polgami sangatlah ramai dibincangkan. Menurut sebagian ulama mangatakan bahwa perintah poligami ini bersifat normatif. Artinya, ketentuan ini berlaku untuk sepanjang masa dan memang harus dilakukan. Sedangkan menurut kalangan modernis, mengatakan bahwa ayat tentang poligami itu tidak hanya bersifat normatif, akan tetapi memiliki sisi historis-kontektual, yang tujuan syar'inya tidak hanya melegalisir poligami itu sendiri, tetapi semangat penegakan keadilan terhadap hak-hak perempuan. ${ }^{9}$

\section{Biografi Fazlu Rahman}

Fazlu rahman dilahirkan di daerah yang stategis untuk perkembangan pemikiran Islam, karena pada masa itu lahir pemikirpemikir ternama seperti Muhammad Iqbal dan Syah Waliyullah. Beliau lahir pada 21 September di Hazarah daerah barat laut Pakistan. Ayahnya adalah ulama ternama di daerahnya, beliau bernama Maulana Syahab al-Din. ${ }^{10}$

Orang yang berperan penting dalam cara berpikir fazlu rahman adalah keluarganya sendiri, pengajaran Ibunya tentang kejujuran, kasih sayang, dan kecintaan serta pengajaran di rumah oleh ayahnya menciprtakan karakter cara berpikir fazlu Rahman, sehingga mampu menghadapi berbagai macam permasalahan dan tantangan dunia modern. Beliau diajarkan oleh orang tuanya mazhab fiqih Hanafi, akan tetapi pada saat itu berkembang pemikiran agak liberal seperti Syah Waliyullah, Syah Abdul Aziz, Sayyid Ahmad Syahid, Sayyid Ahmad Khan, Sayyid Amir Ali dan Sir Muhammad Iqbal, dan ini juga mempengaruhi pola berpikir Fazlu Rahman. ${ }^{11}$

Beliau dididik oleh ayahnya secara tradisional, akan tetapi ayahnya tidak menolak kemodernan. Fazlu Rahman melanjutkan studinya ke sekolah modern dan beliau menyelesaikan program BA- 
nya dalam bidang sasta di Universitas Punjab. Dua tahun selanjutnya beliau menyelesaikan magesternya dalam bidang yang sama di universitas yang sama pula. Selanjutnya beliau melanjutkan program doktornya ke Inggris di Universitas Oxford. Beliau menyelesaikan pendidikan dalam bidang filsafat islam di bawah bimbingan Prof. S. Van Den Bergh dan H. A. R. Gibb, desertasi beliau yaitu tentang Ibnu Sina. ${ }^{12}$ Sambil belajar di sana, beliau menggunakan kesempatan ini untuk mempelajari bahasa asing, sehingga beliau menguasai bahasa Latin, Yunani, Inggris, Jerman, Persia, Turki, Arab dan Urdu.

Lalu beliau diminta oleh Presiden Pakistan untuk menjadi salah satu lembaga riset. Beliau menerima penawaran dari Presiden Pakistan dan belaiu berkiprah di Lembaga Riset Islam Pakistan serta beliaupun diangkat sebagai Dewan Penasehat Ideologi Negara Islam Pakistan yang tugasnya adalah meninjau seluruh hukum. Belaiu menerima tawaran ini dengan harapan dapat memberikan sumbangsi dalam pembaharuan hukum Islam. Di sini, beliau menerbitkan jurnalnya yaitu Dirasah Islamiyah dalam bahasa Arab, Islamic Studies dalam bahasa Inggris dan Fikr-O-Nazr dalam bahasa Urdu. ${ }^{13}$

Gagasan Fazlu Rahman ternyata banyak kontroversi, ungkapannya bahwa "secara keseluruhanyya, al-Qur'an adalah kalam Allah dan dalam pengertiannya bisa juga merupakan perkataan Nabi saw" yang beliau tulis dalam artikelnya yang diterbitkan dalam bahasa Urdu menyulut protes dari banyak pihak, sampai-sampai beliau dituduh sebagai munkiru al-Qur'an. Karena gagasannya tidak banyak diterima, akhirnya beliau mengudurkan diri dari jabatannya. ${ }^{14}$ Lalu beliau meninggalkan Pakistan ditengah hujatan dan sorotan kritik atas gagasannya sampai dianggap terlalu liberal. Selanjutnya beliau menjadi tamu di Universitas California, Los Anggles dan ditarik ke Universitas Chicago sebagai profesor pemikiran islam serta beliau diangkat sebagai guru besar di Chicago University, beliau wafat pada bulan Juli $1998 .^{15}$

\section{Teori Double Movement Fazlu Rahman}

Double Movement Teori adalah pola kombinasi penalaran induksi dan deduksi; pertama, dari yang khusus (partikular) kepada yang umum (general), dan kedua, dari yang umum kepada yang khusus, sehingga dikenalah dua gerakan yang disebut double movement. Ada juga yang berpendapat bahwa double movement itu adalah sebuah metode dengan menggunakan pendekatan sosio-historis dan teori ini memiliki dua gerakan. ${ }^{16}$ 
Gerakan pertama dengan cara memahami arti atau makna dari teks sekaligus mengkaji situasi atau problem historis yang menyebabkan teks itu muncul. Dengan kata lain, gerakan pertama ini menuntut pemahaman teks al-Qur'an secara keseluruhan sekaligus memahami konteks yang khusus tersebut dan selanjutnya diambil hukum umum dari kasus tersebut yang dianggap sebagai pesan moralnya. ${ }^{17}$ Artinya dalam gerakan ini memahami teks yang mempunyai pesan universal dan mengkaji konteks sejarah atau penyebab teks itu diturunkan serta menarik hukum umum dari kejadian tersebut. Sebagaimana yang dikatakan Fazlu rahman sendiri :

Gerakan pertama melibatkan pemahaman terhadap prinsip Alquran dengan Sunah sebagai bagian organisnya. Sektor sosial perintah-perintah Alquran memiliki suatu latar belakang situasional, sebagaimana pewahyuan Alquran sendiri yang memiliki latar belakang religio-sosial masyarakat Makkah pada awal Islam; perintah-perintah Alquran muncul tidak dalam suatu kevakuman, tetapi selalu turun sebagai solusi terhadap masalah-masalah aktual. Latar belakang situasional ini, yang disebut "sebab-sebab pewahyuan".

Gerakan kedua, setelah mencari pesan inti atau tujuan-tujuan (pesan moral) yang mendasari teks itu diturunkan, selanjutnya menarik pesan-pesan tersenbut ke konteks kekinian. Sehingga pesan al-Qur'an yang universal itu dapat diterapkan kepada konteks kekinian. ${ }^{18}$

“... adalah metode berpikir dari yang umum kepada yang khusus. Kumpulan prinsip yang diperoleh dari Alquran lewat cara di atas (yakni dalam gerakan pemikiran pertama), harus diterapkan terhadap masyarakat Muslim dalam konteks dewasa ini. Sebagaimana dengan latar belakang ajaran Alquran yang harus dikaji untuk memperoleh prinsip-prinsip umum Alquran, maka situasi kontemporer juga harus dikaji untuk diambil darinya prinsip-prinsip tentang penerapan hukum terhadap situasi tersebut... Jenis penelitian sosiologis terhadap situasi kontemporer ini akan memberi indikasi yang tepat tentang bagaimana prinsip-prinsip yang diperoleh dari Alquran dan Sunah harus ditubuhkan dalam legislasi kontemporer."

Dapat dikatakan bahwa gerakan pertama merupakan kerja ahli sejarah, sedangkan gerakan kedua merupakan kerja ahli etika. Jika berhasil mencapai kedua gerakan tersebut dengan benar, maka perintah-perintah al-Qur'an akan kembali hidup dan efektif pada saat ini. Dari gerakan ke dua terlihat bahwa Fazlu rahman beranjak dari metodologi ushul fiqh lama yang cenderung literalis, menuju penggunaan pertimbangan ilmu bantu yang bersifat kealaman maupun 
humaniora tujuannya agar para mujtahid mendapat pesan moral yang benar dan tidak terjebak pada pemahaman yang literal saja. ${ }^{19}$ Fazlu Rahman memaknai model di atas sebagai upaya memahami makna suatu teks masa lampau dan konteks di masa lampau untuk kemudian mengubah aturan tersebut, baik itu memperluas, membatasi, ataupun memodifikasi sehinggga tepat untuk situasi yang baru. Dengan demikian, satu teks dapat digeneralisasi sebagai suatu prinsip dan prinsip tersebut sebagai aturan baru untuk situasi yang baru pula.

\section{E. Penerapan Teori Double Movement dalam Kasus Pologami}

Langkah pertama : yaitu melihat konteks ketika hukum poligami itu disyariatkan dan mencari nilai universal dari pensyariatan hukum poligami.

Pada masa islam belum datang, nasib perempuan begitu sangat mengkhawatirkan, ini terlihat dari kebiasaan-kebiasaan yang diperlakukan terhadap perempuan. Adanya kebiasaan pembunuhan anak perempuan karena dianggap sebagai aib jika anak perempuan itu ditangkap dan ditawan musuh serta mereka dijadikan pemuas syahwat belaka. Selain itu ketika perempuan dalam masa iddahnya, mereka biasanya dikurung di kamar kecil, tidak boleh menyentuh apapun, tidak boleh berdandan walaupun sekedarnya bahkan tidak boleh menyisir sekalipun. ${ }^{20}$

Selain tradisi di atas, adanya sistem perkawinan istibda' yaitu seorang suami menjauhi istrinya untuk waktu tertentu dan menyuruh istrinya agar berhubungan dengan laki-laki yang lain untuk mendapatkan keturunan yang lebih baik setelah isterinya hamil, suaminya berhubungan lagi dengan isterinya, dan ada juga sistem perempuan itu didatangi oleh banyak lelaki dan berhubungan dengan mereka, lalu setelah dia hamil dia meminta salah seorang dari laki-laki itu untuk menjadi suaminya. Selain itu ada model-model perkawinan tanpa mahar seperti perkawinan sigar dan za'inah serta ada juga perkawinan daizan yaitu perkawinan antara anak laki-laki tertua dengan istri ayahnya karena ayahnya sudah meninggal. ${ }^{21}$ Semua hal di atas adalah bukti konkreat akan rendahanya martabat perempuan dikala itu.

Terkait dengan ayat yang membolehkan poligami Wahba Juhaili berpendapat bahwa pada zaman sebelum nabi datang, orang arab bisa menikahi sepuluh perempuan, bahkan bisa lebih dan bisa juga kurang. Itu jelas adalah sebuah kezaliman, untuk membatasi kezaliman dengan cara membatasi dengan hanya empat orang istri saja dengan syarat harus adil juga. Persyaratan adil ini sangat sulit untuk dilakukan oleh 
para suami, maka pada dasarnya ayat ini memerintahkan untuk mencukupankan satu orang istri saja. ${ }^{22}$

Ini dibuktikan dengan hadist yang diriwayatkan oleh Abu Dawud dari Harits bin Qais berkata "Aku baru masuk islam sedangkan istriku berjumlah delapan orang. Ketika itu aku mengatakannya kepada Rasul, Rasul berkata kepadaku pilihlah empat orang saja di antara mereka". ${ }^{23}$ Dalam hadist ini mengisyaratkan bahwa pernikahan lebih dari empat sudah terjadi pada zaman sebelum islam datang. Bahkan pada waktu itu setiap laki-laki bebas menikahi berapa saja jumlanya sesuai keinginan laki-laki. ${ }^{24}$ Akan tetapi pembatasan yang menjadi empat orang adalah pembatasan yang sangat signifikan. Artinya pembatan ini mengisyaratkan secara halus untuk menghilangkan praktik poligami. Akan tetapi islam tidak melarangnya secara provokatif dan radikal, islam melarangnya secara gradual sebagaimana yang dilakukan terhadap pelarangan minum khamar.

Pada hakikatnya, nilai moral yang terkandung dalam pembatasan ini adalah untuk mengangkat harkat martabat perempuan yang aslanya pada masa itu "tidak memiliki nilai" di mata laki-laki.

Langkah ke dua : menarik nilai moral itu ke dalam konteks ke kinian.

Pada masa ini, kedudukan perempuan sudah sangat berbeda kondisinya dengan kedudukan pada masa pra-islam. Bahkan perempuan bisa dikatakan mempunyai kedudukan yang setara dengan laki-laki dalam beberapa kondisi, seperti dalam pekerjaan, politik dan lain sebagainya. Perempuan mempunyai kesempatan yang sama dengan laki-laki dalam beberapa hal.

Pada saat ini perempuan mempunyai independensi yang besar dalam melakukan aktifitasnya. Banyak diantara mereka yang memliki kemahiran yang lebih dari pada laki-laki dalam menjalani profesi di sektor publik. Perempuan mempunyai kesempatan besar dalam masalah ekonomi bahkan mereka mempunyai istilah tersendiri untuk orang-orang seperti itu yaitu wanita karier. Bahkan disebagian kasus, perempuan lebih mampu mencari nafkah untuk keluarganya. ${ }^{25}$ Artinya sistem sosial sudah tidak patriaki lagi, akan tetapi laki-laki dan perempuan mempunyai kedudukan dan kesempatan yang sama.

\section{F. Kesimpulan}

Dari uraian di atas dapat disimpulakan bahwa kebolehan beristri lebih dari satu atau poligami dikarenakan kedudukan perempuan pada saat itu "tidak ada nilainya di mata laki-laki" dikarenakan sitem yang digunakan adalah sistem sistem patriaki. 
Pembatasan kebolehan menikahi empat perempuan sebenarnya menyimpan nilai moral yaitu untuk mengangkat harkat dan martabat perempuan. Akan tetapi, dalam konteks hari ini di mana perempuan memiliki kedudukan yang sama dengan laki-laki, maka dari itu poligami pada masa ini tidaklah diperbolehkan.

${ }^{1}$ Abdul Kallaf Wahab, Ilmu Ushul Fiqh Cet I (Bandung : Geman Risalah Press, 1996) hal 111.

${ }^{2}$ An-Nisa : 3

${ }^{3}$ Muhammad Bagir al-Habsyi, Fiqih Praktis : Menurut al-Qur'an, as-Sunnah dan Pendapat Ulama Cet I (Bandung : Mizan, 2002) hal 90.

${ }^{4}$ Ahmad Zahari, Telaah terhadap Poligami dalam Persfektif Hukum Islam (Pontianak : MMH Jilid 43) hal 9.

${ }^{5}$ M. Ahmad Amin, Memaknai ar-Ruju Ila Qur'an wa as-Sunnah, hal 63.

${ }^{6}$ Labib Muttaqin, Aplikasi Teori Double Movement Fazlu Rahman Terhadap Doktrin Kewarisan Islam Klasik (Malang : al-Manahij Vol 7, 2013) hal 196.

7 Lum'atus Sa'adah, Transformasi Fikih Klasik Menuju Fikih Kontemporer : Sebuah Tawaran Penemuan Hukum Islam Melalui Metode Double Movement (Jakarta : Jurnal Falasifa, 2012) hal 3.

${ }^{8}$ Mansur, Dekontruksi Tafsir Poligami : Mengurai Dialektika Teks dan Konteks (al-Ahwal : Yogyakarta, 2008) hal 32-33.

${ }_{9}$ Mansur, Dekontruksi Tafsir Poligami : Mengurai Dialektika Teks dan Konteks (al-Ahwal : Yogyakarta, 2008) hal 43.

10 Fazlu Rahman, Gelombang Perubahan dalam Islam : Studi Tentang Fundamentalisme Islam (Jakarta : Raja Grafindo, 2001) hal 5.

${ }_{11}$ M. Hasbi, Amiruddin, Konsep Negara Islam Menurut Fazlu Rahman (Yogyakarta : UII Press, 2000) hal 9.

${ }^{12}$ Taufiq Adnan Amal, Islam dam Tantangan Modernitas Cet III (Bandung : Mizan, 1992) hal 81.

13 Taufiq Adnan Amaml, Islam dalam Tantangan Modernitas Cet III (Bandung : Mizan, 1992) hal 14.

${ }^{14}$ John Esposito, Pakistan : Pencarian Identitas Islam, dalam Islam dan Perubahan Sosial Politik di Negara Berkembang, terjemahan Wardah Hafiz (Yogyakrta : PLP2M, 1985) hal 286.

${ }^{15}$ Abd. A'la, Dari Neo-Modernisme ke Islam Liberal : Jejak Fazlu Rahman dalam Wacana Islam di Indonesia (Jakarta : Paramadina, 2003) hal 37.

${ }^{16}$ Subwaihi, Hermenetika al-Qur'an Fazlu Rahman (Bandung : Jalasutra, 2007) hal 52.

17 Fazlu Rahman, Islam Modernitas : Tentang Transformasi Intelektual terjemahan Ahsin Muhammad Cet II (Bandung : Pusaka, 1995) hal 7.

18 Fazlu Rahman, Islam Modernitas : Tentang Transformasi Intelektual terjemahan Ahsin Muhammad Cet II (Bandung : Pusaka, 1995) hal 7.

${ }^{19}$ Labib Muttaqin, Aplikasi Teori Double Movement Fazlu Rahman (Malang : al-Manahij, 2013) hal 196.

20 Asep Dadang Abdullah, Konsep Iddah Bagi Suami (Semarang : IAIN Walisongo, 2014) hal 37.

${ }_{21}$ Asep Dadang Abdullah, Konsep Iddah Bagi Suami (Semarang : IAIN Walisongo, 2014) hal 47-48 
${ }^{22}$ Wahba Juhaili, Tafsir al-Washit Jilid 1 (Jakarta : Gema Insani, 2012) hal 253-254.

${ }^{23}$ Muhammad Bagir al-Habsyi, Fiqih Praktis : Menurut al-Qur'an, asSunnah dan Pendapat Ulama Cet I (Bandung : Mizan, 2002) hal 92.

${ }^{24}$ Muhammad Bagir al-Habsyi, Fiqih Praktis : Menurut al-Qur'an, asSunnah dan Pendapat Ulama Cet I (Bandung : Mizan, 2002) hal 93.

${ }^{25}$ Labib Muttaqin, Aplikasi Teori Double Movement Fazlu Rahman terhadap Doktrin Kewarisan Islam Klasik Vol 2 (Malang : al-Manahij, 2013) hal 202. 